\title{
THE EFFECTS OF PHYSICAL EXERCISES ON C-REACTIVE PROTEIN IN PATIENTS WITH POST ISCHEMIC STROKE
}

\author{
Hening Laswati, Meisy Andriana, Imam Subadi, Ida Yuanita \\ Department of Physical Medicine and Rehabilitation, Faculty of Medicine, Universitas Airlangga, \\ Dr Soetomo General Hospital, Surabaya
}

\begin{abstract}
ABSTRAK
Beberapa studi akhir-akhir ini menekankan pentingnya peran latihan fisik dalam regulasi status inflamasi, tetapi level marker inflamasi setelah latihan fisik pada pasien pasca stroke iskemia masih belum banyak diketahui. Tujuan penelitian ini untuk mengetahui efek latihan fisik menggunakan Partial Body-Weight Supported Treadmill Training-Audio Cues (PBWSTT-AC) dan latihan fisik metode Tradisional pada pasien pasca stroke iskemia terhadap kadar marker inflamasi C-Reactive Protein (CRP). Penelitian ini menggunakan rancangan pretest-postest control group, 14 pasien pasca stroke iskemia dilakukan randomisasi dan di alokasikan ke dalam 2 kelompok: Kelompok 1 (kontrol) mendapat latihan berjalan metoda Tradisional, dan kelompok 2 mendapat latihan berjalan dengan PBWSTT-AC. Perlakuan ini dilakukan selama 20 menit 3 kali dalam satu minggu hingga 12 sesi. Sebelum perlakuan dan setelah 12 sesi (4 minggu) latihan dilakukan pemeriksaan CRP menggunakan pemeriksaan imunoserologi. Analisis statistik menggunakan SPSS 17 dan dengan signifikansi p <0,05 untuk semua analisis statitik. Untuk komparasi level CRP diantara 2 kelompok tersebut data yang diperoleh dianalisis menggunakan Student t test dan Mann-Whitney test. Hasil penelitian ini menunjukkan bahwa tidak ada perbedaan yang signifikan kadar CRP diantara kedua kelompok setelah perlakuan ( $p=0,898)$ yang menunjukkan bahwa kadar CRP pasca stroke iskemia tidak dipengaruhi oleh metoda atau jenis latihan fisik yang diberikan. Sebagai kesimpulan, baik latihan dengan metode tradisional maupun PBWSTT-AC dalam waktu 4 minggu tidak menunjukkan efek perubahan konsentrasi CRP. (FMI 2016;52:180-184)
\end{abstract}

Kata kunci: stroke, latihan fisik, CRP

\begin{abstract}
Several studies have recently highlighted the important role of physical exercise in regulation inflammatory status, but there is relatively little known about markers of inflammation levels after physical exercise in post ischemic stroke patients. The aims of this study to provide the effects of physical exercise using Partial Body-Weight Supported Treadmill Training -Audio Cues (PBWSTT$A C)$ and Traditional method on the level of inflammatory markers C-Reactive Protein (CRP). This study using pretest-postest control group design, 14 post ischemic stroke patients were randomized and allocate to two groups: Groupl (control group) received traditional walking exercise and group 2 received PBWSTT-AC. The walking exercise study were conducted for 20 minute 3 times a week for 12 sessions (4 weeks). Before and after 12 session of exercises, the serum levels of CRP were determined using immunoserology. All statistical test were carried out using SPSS 17 and statistical significance was set at p<0.05 for all analysis. The CRP levels between group were compared using Student t test or Mann-Whitney test. From multiple comparisons statistic result, no significant difference between groups $(p=0.898)$, that seem in this study the levels of CRP of poststroke patients is not influenced by the Traditional training and PBWSTT-AC. The conclusion of this study that both traditional method and PBWTT-AC in 4 weeks exercise training seem have no effect on CRP levels. (FMI 2016;52:180-184)
\end{abstract}

Keywords: stroke, physical exercise, $C R P$

Correspondence: Hening Laswati, Department of Physical Medicine and Rehabilitation, Faculty of Medicine, Airlangga University, Dr Soetomo General Hospital, Surabaya. Phone: 0315501493. e-mail: 1putra04@yahoo.com

\section{INTRODUCTION}

Measurements of inflammatory marker like C-Reactive Protein (CRP) is highly predictive of future risk of stroke and poor outcome after ischemic stroke. High levels of C-Reactive Protein (CRP) are prevalent in all ischemic stroke subtypes with a 3 times increase in risk developing cardioembolic stroke and 2 times raise in risk of large artery atherosclerosis (Chaudhuri et al 2013). C-Reactive Protein (CRP), is a glycoprotein, non-specific but a sensitive marker of inflammation, is an active mediator of atherogenesis and associated with increased lymphocyte infiltration and poorer recovery of brain tissue (Chaudhuri et al 2013, Danzig et al 2010, Whiteley et al 2009). Plasma CRP is predominantly produced by the hepatocytes, although has also produced by lymphocytes, monocytes, neurons, atherosclerosis plaques and some tumors. It is regulated by IL6 , TNF- $\alpha$ and IL-1 $\beta$ (Ho et al 2009). The increased circulating of IL-6 will induce the hepatic synthesis of 
CRP. This markers of inflammation contributes to the development of progression of atherosclerosis through binding to phospholipids of damaged cells to activate complement, increased of LDL uptake by macrophages, endothelial expression of cell adhesion molecules (CAMs) and plasminogen activator inhibitor (PAI)-1 expression, and the decrease of Nitric Oxide (NO) production through decreasing expression and bioviability of eNOS (Kasapis \& Thompson 2005, Riberiro et al 2010). Berezin \& Lisovaya (2014) reported that hsCRP levels $>5.58 \mathrm{mg} / \mathrm{L}$ is strongly predict increased risk of cumulative cardivascular events after ischemic stroke in hypertensive patients. The CRP levels increases significantly during the first $48 \mathrm{~h}$ after onset and associated with stroke subtype and lateralization phenomenon (Berezin \& Lisovaya 2014). In an acute phase, CRP synthesized by liver within 6 hours of inflammatory stimulus such as acute ischemic stroke, and half life is 19 hours (Rajput et al 2011).

A cross sectional studies reported inverse relationship between physical activity and CRP levels (Kasapis \& Thompson 2005). The possible inflammation lowering effect of exercise training can explain the benefits of regular physical exercise for preventing stroke. From in vitro studies showed that application of laminer shear stress to cultured endothelial cells activates endothelial nitric oxide synthase (eNOS), as well as the cytosolic copper/zinc-containing superoxide dismutase pathway that condition contribute to attenuating the formation of foam cells and vascular inflammation (Danzig et al 2010, Riberiro et al 2010). Not all the studies reported that exercise reduced CRP levels and the exact mechanism by which physical exercise reduces CRP is not clear. Exercise training, including the use of bodyweight support in treadmill combined with auditory feedback (audio cues) is a rehabilitation intervention used to improve endurance capacity and ability to walk after stroke. Both methods show similar efficacy in improving self-selected walking speed, but PBWSTTAC was shown to be superior in improving cardiorespiratory fitness (Laswati et al 2015). Until now the effect of both methods on CRP levels have not known yet. The objective of this study is to know the effect of two methods of physical exercise (Traditional and PBWSTT-AC) on CRP levels in patient with post ischemic stroke in outpatient clinic, Instalation of Medical Rehabilitation Dr Soetomo General Hospital Surabaya.

\section{MATERIALS AND METHODS}

Patients with sub-acute and chronic ischemic stroke who referred to Department of Physical Medicine and Rehabilitation with onset 3 weeks until 10 years, age between 21 until 70 years old, can walk independently for 6 minutes with or without ambulation aids or orthosis, sufficient vision and hearing and can follow simple commands were included in this study. Subjects with uncontrolled hypertension, cardiorespiratory problems, apraxia, severe hemispatial neglect, aphasia, musculoskeletal disturbances, severe spasticity, tremor, ataxia, sensory disturbances were excluded. Fourteen patients who fulfilled the inclusion criteria were randomized and allocate to two groups. Control subjects received traditional over ground walking exercise with speed according to the patient's preference for 20 minutes three times a week for 12 session. Patients in the intervention group underwent walking exercises for 20 minutes three times a week for 12 session in PBWSTT-AC (Biodex Gait Trainer 2 and Unweighing System) with metronome auditory rhythmic stimulation ( $125 \%$ of step cycle's rhythm from baseline based) to optimize learning process (Lee et al 2012). The study were conducted in Airlangga University Hospital. Approval was obtained from dr Soetomo General Hospital Ethics Commitee. Before and after 12 session of exercises, the serum levels of hsCRP were determined using enzym-linked immunoassay (ELISA). All statistical test were carried out using SPSS 17. Statistical calculation were performed using Student ttest or Mann-Whitney test, and correlation between baseline CRP and age, BMI, onset were analysis using Pearson correlation test, with $\mathrm{p}<0.05$ considered significant.

\section{RESULTS}

The study recruited a total 14 patients of post ischemic stroke, 5 men and 2 women in the control group and 3 men and 4 women in PBWSTT-AC group. Baselines characteristics are shown in table 1. No differences between the Traditional method and PBWSTT-AC group were found in the baseline characteristics (BMI , age and onset).

Statistical analysis with the Wilcoxon Signed-Rank Test showed no significant difference $(p=0.128)$ the CRP levels before and after exercise training in the control (traditional) group. In PBWSTT-AC group, analysis with T-Test also showed no significant difference $(p=0.634)$ the CRP levels before and after physical exercise. There is no significant difference the post intervention CRP levels between Traditional and PBWSTT-AC group $(\mathrm{p}=0.898)$. No significant correlation between pre intervention CRP levels and BMI $(\mathrm{r}=0.640, \mathrm{p}=0.828)$; CRP levels and age $(\mathrm{r}=0.291$, $\mathrm{p}=0.313)$ and CRP levels and onset of stroke ( $\mathrm{r}=-0.421$, $\mathrm{p}=0.134)$. 
Table 1. Baseline characteristic of post ischemic stroke patients enrolled in the study

\begin{tabular}{|c|c|c|c|c|c|}
\hline & $\mathrm{X}$ & SD & Min & Max & $\mathrm{P}$ \\
\hline \multicolumn{6}{|l|}{ BMI } \\
\hline - $\quad$ Traditional & 25.91 & 2.82 & 23.11 & 30.60 & 0.200 \\
\hline - $\quad$ PBWSTT-AC & 23.83 & 4.51 & 18.97 & 30.04 & 0.200 \\
\hline \multicolumn{6}{|l|}{ Age (years) } \\
\hline - $\quad$ Traditional & 55.00 & 6.87 & 44.00 & 64.00 & 0.200 \\
\hline - $\quad$ PBWSTT-AC & 51.00 & 12.25 & 33.00 & 65.00 & 0.200 \\
\hline \multicolumn{6}{|l|}{ Onset (months) } \\
\hline - $\quad$ Traditional & 8.71 & 8.40 & 1.00 & 24.00 & 0.200 \\
\hline - $\quad$ PBWSTT-AC & 5.39 & 4.61 & 0.75 & 14.00 & 0.200 \\
\hline
\end{tabular}

Table 2. The distribution levels of CRP among the control and PBWSTT groups before and after 12 session exercise

\begin{tabular}{llccccc}
\hline & & \multicolumn{3}{c}{ CPR (mg/L) } & & P \\
\cline { 3 - 6 } & & $\mathrm{X}$ & $\mathrm{SD}$ & $\mathrm{Min}$ & $\mathrm{Max}$ & 0.475 \\
\multirow{2}{*}{ Traditional } & Pre & 3.75 & 2.73 & 0.80 & 8.50 & $0.010^{*}$ \\
& Post & 2.12 & 1.28 & 0.90 & 4.90 & 0.396 \\
\multirow{2}{*}{ PBWSTT } & Pre & 1.81 & 1.30 & 0.40 & 4.30 & 0.397 \\
\hline
\end{tabular}

Post intervention CRP levels from traditional (control) group is not within normal distribution.

Table 3. The CRP levels before and after 12 session exercise

\begin{tabular}{lccc}
\hline & Traditional & PBWSTT-AC & $p$ value \\
& $\mathrm{N}=7$ & $\mathrm{~N}=7$ & 0.898 \\
\hline Baseline $(\mathrm{mg} / \mathrm{L})$ & $3.75 \pm 2.73$ & $1.81 \pm 1.30$ & \\
After 12 session $(\mathrm{mg} / \mathrm{L})$ & $2.12 \pm 1.28$ & $2.00 \pm 1.22$ & \\
$p$ value & 0.128 & 0.634 & \\
\hline
\end{tabular}

\section{DISCUSSION}

Many neurorehabilitation protocol used in walking rehabilitation using PBWSTT, but there was no concensus between the experts about the optimal technique and prescriptions (Duncan et al 2011, Peurala et al 2005). The result in this study showed that exercise training with traditional method and using PBWSTT$\mathrm{AC}$ for 4 weeks have no effect on CRP levels. The results were same with the recent studies. Two recent studies (exercise for 4 and 7 weeks) failed to confirm the effect on CRP levels, the CRP levels showed decreased after following 7 week exercise without reaching statistical significance. From meta-analysis studies, it was seem that the duration to be crucial, at least a 12 weeks showed decreasing of CRP levels (Riberiro et al 2010, Rathod et al 2015). How exercise suppresses CRP levels is not well defined. It suggest that long term physical exercise attenuates the inflammatory and atherogenic cytokines (IL-1, IL6 and TNF- $\alpha$ ) and reduces the CRP production from liver (Rathod et al 2015). Long term exercise also upregulation of antioxidant enzymes (Kasapis \& Thompson 2005). The Joint American Heart Association Guidelines and American Stroke Association recommend 30 minutes of moderate intensity activity daily
(Ahmed et al 2012). In this study the duration of conditioning exercise training 20 minutes, with warmup 15 minutes and cooling down for 15 minutes for four weeks. The different result may be due to a factor of subject characteristics, the timing of the blood samples taken and the type, intensity and duration of the exercise intervention. In asymptomatic men, CRP is inversely correlated with maximal oxygen uptake and maximal working capacity (Danzig et al 2010). In cross-sectional and longitudinal studies have shown associations of high levels of IL-6 and/or CRP with low physical performance and disability.The Longitudinal Aging Study Amsterdam reported in the prospective study reported that higher levels of CRP increase risk of muscle strength loss in older persons (Schaap et al 2006). In the Cardiovascular Health (CH) Study, CRP levels were significantly lower in which total energy expenditure was estimated to be just 368-1050 $\mathrm{kcal} /$ week and there were found an inverse relationship between walking speed and IL-6 and CRP levels (Wood et al 2012).

Some studies reported that high initial CRP levels in sedentary healthy adults are reduced in response to exercise (Rathod et al 2015). Another studies have shown an inverse relation between physical activity and 
CRP, and have noted greatest reduction in high baseline CRP levels (>3.0 mg/L) (Ahmed et al 2012). In this studies the mean of CRP levels from control group $>3.0$ $\mathrm{mg} / \mathrm{L}$, showed decreased CRP levels after 4 weeks exercise training (traditional method) without reaching statistical significance. The Health, Risk Factors, Exerccise Training and Genetics (HERITAGE) Family Study observed no statisctically significant reduction in CRP across 490 participants with baseline CRP levels $<3.1 \mathrm{mg} / \mathrm{L}$ (Berezin \& Lisovaya 2014). From PBWSTT-AC group in this study showed the baseline CRP levels $<3.1 \mathrm{mg} / \mathrm{L}$, and there was no reduction of CRP levels after exercie training for 4 weeks. Study in subjects suspected of coronary artery disease, a symptom-limited exercise stress test induced increase in CRP significantly. The results indicate that the exercise has potential to cause unwanted variations of CRP (Mouridsen et al 2014).

Obesity has been linked to CRP in large number of cross-sectional studies (Choi et al 2013). In central obesity increased production of IL- 6 and TNF- $\alpha$ by adipocyte cells associated with CRP levels (Reberiro et al 2010). Accumulation of free fatty acid intermediates activates proinflammatory serine kinase cascades that promote the secretion of cytokines (IL-6), and trigger the hepatic synthesis of CRP (Choi et al 2013). Physically active individuals have less adipocytes, less secretion of leptin and less produce inflammatory cytokines, this lead to decreased hepatic CRP production. Exercise training that results in fat loss is effective at reducing CRP and one study reported that the effect of exercise on CRP was restricted to women who were obese (BMI >30kg/m2) (Wood et al 2012). In coronary artery disease patients with and without metabolic syndrome after 3-month exercise training the CRP levels decreased significantly. Six months of exercise in individuals at risk of developing ischemic heart disease reflected decreased CRP levels by $35 \%$ although without reaching statistical significance (Reberiro et al 2010). The recent study reported the reduction of CRP in patients who showed no improvement in BMI (Kasapis \&Thompson 2005, Reberiro et al 2010), but other studies have been shown in both genders, CRP levels were positively correlated to measures of adiposity, but were not related to physical acitivity levels itself (Wood et al 2012). In this sudy showed no correlation between baseline BMI with the baseline CRP levels in the traditional method group and PBWSTT-AC group. Stroke severity, premorbid disability, and age may be strongly associated with marker levels (Whiteley et al 2009). In this study there were no association between age and the onset of stroke with the baseline of CRP levels in the traditional method group and PBWSTT-AC groups.

\section{CONCLUSIONS}

Both traditional method exercise training and PBWTTAC for 4 weeks (12 sessions) showed failed to confirm the effect on CRP levels. The majority of evidence suggest that exercise training more than 12 weeks reduce the circulating levels of CRP. Future research with longer intervention (more than 4-week) of both method exercise training is needed to induce significant improvement of CRP levels.

\section{REFERENCES}

Ahmed, HM, Blaha, MJ, Nasir, K, Rivera, JJ, \& Blumenthal, RS 2012, ' Effects of Physical Activity on Cardiovascular Disease', Am J Cardiol, vol. 109, pp. 288-295

Berezin, AE, \& Lisovaya, OA 2014,' C-reactive protein after stroke in arterial hypertension', Asian

Cardiovascular and Thoracic Annals, vol. 22, no. 5, pp. $551-557$

Chaudhuri, JR, Mridula, KR, Umamahesh, M, Swathi, A, Balaraju, B, \& Bandaru, VCS 2013, 'High Sensitivity C-Reactive Protein Levels in Acute Ischemic Stroke and Subtypes: A Study from a Tertiary Care Center', Ir J Neurol, vol.12, no.3, pp. 92-97.

Choi, J, Joseph, L, \& Pilote, L 2013, ' Obesity and CReactive Protein in Various Populations: a systemic review and meta-analysis', Obesity reviews, vol. 14, pp. 232-244.

Danzig, V, Mivkova, B, Kuchynka, P, Benkova, H, Zima, T, Kittnar, O, Skrha, J, Linhart, A, \& Kalousova, M 2010, 'Levels of circulting Biomarkers at rest and after Exercise in Coronary Artery Disease Patients', Physiol.Res, vol. 59, pp. 385-392.

Duncan, PW, Sullivan, KJ, Behrman, AL, Azen, SP, Wu, SS, Nadeau, SE, Dobkin, BH, Rose, DK, , Tilson, JK, Cen, S, \& Hayden, SK 2011, 'Body-WeightSupported Treadmill Rehabilitation after Stroke', N Engl J Med, vol. 364, pp. 2026-36

Ho, KM 2009, 'C-Reactive Protein as a Prognostic Indicator in Clinical Medicine', Scientific Medicine, vol. 1, no.2, pp.1-5

Kasapis, C, \& Thompson, PD 2005, ' The effecs of Physical activity on serum C-Reactive Protein and inflammatory markers', JAAC, vol. 45, no. 10, pp. 1563-68

Laswati, H, Andriana, M, \& Yuanita, I 2015, 'Effectiveness of Partial Body-Weight Supported Treadmill Training-Audio Cues and Traditional Overground Walking in Improving Gait Speed and Cardiorespiratory Fitness after Stroke', Indonesian Journal of Physical medicine \& Rehabilitation, vol. 04, pp. 9-15. 
Lee,SH, Lee, KJ, \& Song, CH 2012,' Effects of Rhythmic Auditory Stimulation (RAS) on gait Ability and Symmetrtry after Stroke', J Phys Ther Sci, vol. 24 , no. 4 , pp. $311-314$

Mouridsen, MR, Nielsen, OW, Carlsen, CM, Mattsson, N, Ruwald, MH, Binici, Z, \& Sajadich, A 2014, 'High-sensitivity C-reactive protein and exerciseinduced changes in subjects suspected of coronary artery disease', Journal of Inflammation Research, vol.7, pp. $45-55$

Peurala, SH, Tarkka, IM, Pitkanen, K, \& Sivenius, J 2005, 'The effectiveness of Body Weight-Supported Gait Training and Floor Walking in Patients with Chronic Stroke', Arch Phys Med Rehab, vol. 86, pp. 1557-64

Rajput, MR, Lakhair, MA, Shaikh, MA, Rind, MS, Zafarullah, \& Bano, R 2011, 'C-Reactive Protein (CRP) and other Risk Factors in Acute Ischemic Stroke Patients' JLUMHS, vol. 11, no. 3, pp. 131-133.

Rathod, SS, Sagdeo, MM, Date, AA, Nagose, VB, Ankur, \& Praveen, KK 2015, ' Effect of exercise training on C-reactive protein levels: A follow up study', Int J of Med Health Sci. vol. 4, no. 3, pp.:626629

Riberiro, F, Alves, AJ, Duarte, JA, \& Oliveira, J 2010, 'Is exercise training an effective therapy targeting endothelial dysfunction and vascular wall inflammation?, International Journal of Cardiology, vol. 141, pp. 214-221.

Schaap, LA, Pluij, SMF, Deeg, DJH, \& Visser, M 2006, ' Inflammatory Markers and Loss of Muscle Mass (Sarcopenia) and Strength', Am J Med, vol. 526, pp.e9-e17

Whiteley, W, Chong, WL, Sengupta, A \& Sandercock, P 2009, 'Blood Markers for the Prognosis of Ischemic Stroke: A Systematic Review', Stroke, vol. 40, pp.e380-e389.

Woods, JA, Wilund, KR, Martin, SA, \& Kistler, BM 2012, 'Exercise, Inflammation and Aging', Aging and Disease, vol. 3, no. 1, pp. 130-140. 